\title{
CP MAS KINETICS AND IMPEDANCE SPECTROSCOPY STUDIES OF LOCAL DISORDER IN LOW-DIMENSIONAL H-BONDED PROTON-CONDUCTING MATERIALS
}

\author{
L. Dagys ${ }^{\text {a, b}}$, S. Balčiūnas ${ }^{c}$, J. Banys ${ }^{c}$, F. Kuliešius ${ }^{\text {a }}$, V. Chizhik ${ }^{d}$, and V. Balevičius ${ }^{a}$ \\ ${ }^{a}$ Institute of Chemical Physics, Vilnius University, Sauletekio 3, 10257 Vilnius, Lithuania \\ ${ }^{\mathrm{b}}$ Department of Chemistry, University of Southampton, University Road, SO17 1BJ Southampton, UK \\ 'Institute of Applied Electrodynamics and Telecommunications, Vilnius University, Sauletekio 3, 10257 Vilnius, Lithuania \\ ${ }^{\mathrm{d}}$ Faculty of Physics, Saint Petersburg State University, Ulianovskaya 1, 198504 Saint Petersburg, Russia \\ Email: vytautas.balevicius@ff.vu.lt
}

Received 29 May 2019; revised 3 June 2019; accepted 25 June 2019

\begin{abstract}
The ${ }^{1} \mathrm{H}-{ }^{13} \mathrm{C}$ cross-polarization magic angle spinning (CP MAS) kinetics was studied in poly(vinyl phosphonic acid) (pVPA), i.e. material with high degrees of freedom of proton motion along $\mathrm{H}$-bonded chains. It has been shown that the $\mathrm{CP}$ kinetic data for the adjacent ${ }^{1} \mathrm{H}-{ }^{13} \mathrm{C}$ spin pairs can be described in the frame of the isotropic spin-diffusion approach. The rates of spin diffusion and spin-lattice relaxation as well as the parameters accounting for spin coupling and the effective size of spin clusters have been determined. The local order parameter $S \approx 0.63 \pm 0.02$, determined as the ratio of the measured dipolar ${ }^{1} \mathrm{H}-{ }^{13} \mathrm{C}$ coupling constant and the calculated static dipolar coupling constant, is significantly lower than the values deduced for related sites in other polymers and in series of amino acids. This means that the local disorder of the $\mathrm{C}-\mathrm{H}$ bonds in pVPA is between those for rather rigid C-H bond configurations having $S=0.8-1.0$ and highly disordered $-\mathrm{CH}_{3}$ groups $(S \sim 0.4)$. This effect can be attributed to the presence of the proton transfer path where proton motion is easy to activate. The activation energy for the proton motion $E_{\mathrm{a}}=59 \pm 7 \mathrm{~kJ} / \mathrm{mol}$ was determined from the impedance spectroscopy data analysing the temperature and frequency dependences of the complex dielectric permittivity of pVPA. The rates of proton spin-lattice relaxation and spin diffusion are of the same order and both run in the time scale of milliseconds.
\end{abstract}

Keywords: solid state NMR, cross-polarization, impedance spectroscopy, proton conductors, poly(vinyl phosphonic acid)

PACS: $33.25 .+\mathrm{k}, 82.56 .-\mathrm{b}$

\section{Introduction}

Cross-polarization (CP), combined with magicangle spinning (MAS), is one of the 'classical' and most widely used methods in solid-state NMR spectroscopy [1-3]. CP proved to be a powerful tool studying fine structural details and dynamics in advanced complex materials [4-6]. Naturally, carbons and protons are the main available dipolar coupling partners that decide the CP kinetics in most organic molecular systems. The processing of CP kinetic data, i.e. the consideration of the evolution of communication between spins in time (contact time), provides the rates of spin diffusion and spin-lattice relaxation, the profiles of distribution of dipolar coupling and some other parameters accounting for the effective sizes of spin clusters [5-8].

The purpose of the present work was to extend the CP MAS kinetic studies to a very important 
class of matter - to soft low-dimensional protonconducting materials, which possess high degrees of internal freedom for proton motion and proton disorder along the H-bonded chains. It is expected that the subtle coherent $\mathrm{CP}$ effects of quantum nature can be quenched upon increasing the incoherent intramolecular motion and local disorder. This could impede the analysis of experimental data forcing one to create novel models and concepts of processing. The presence of remote spins $\left(\mathrm{POO}^{1} \mathrm{H}\right.$ in the present case) can also influence the extracted ${ }^{1} \mathrm{H}-{ }^{13} \mathrm{C}$ dipolar coupling values that can be misinterpreted as due to a motional effect [9]. Poly(vinyl phosphonic acid) (pVPA) was chosen for these studies for several reasons. pVPA is the phosphonic acid tethered polymer that contains a high concentration of acid groups and adopts a relatively simple structure. Furthermore, phosphonic acid is considered to form a strong hydrogen-bonding network involving both $\mathrm{P}=\mathrm{O}$ and $\mathrm{P}-\mathrm{OH}$ as proton acceptor and proton donor groups. The mobility of the phosphonic acid $\mathrm{POOH}$ groups and their acidic protons in pVPA was studied applying various solid-state NMR techniques [10, 11]. Regarding industrial and other practical aspects, a considerable interest in recent years has arisen in polymer membranes containing phosphonic acid groups as these materials are very promising for fuel cell technologies [11].

Impedance spectroscopy was applied to study the activation energy of mobility of protons along $\mathrm{H}$-bond chains using the experimentally measured temperature and frequency dependences of complex dielectric permittivity.

\section{Experiment}

Poly(vinyl phosphonic acid) (pVPA) was purchased from Sigma-Aldrich and used as received. The chemical structure of pVPA including the possible hydrogen-bond chain is shown in Fig. 1 .

The solid state NMR experiments were performed using a Bruker AVANCE III HD spectrometer with a double resonance CP MAS probe. The experiments were performed in the $9.4 \mathrm{~T}$ magnetic field using an Ascend wide bore superconducting magnet.

The ${ }^{1} \mathrm{H} \rightarrow{ }^{13} \mathrm{C}$ cross-polarization contact for ${ }^{13} \mathrm{C}$ was achieved with a rectangular $71 \mathrm{kHz}$ RF pulses at the $n= \pm 1$ Hartmann-Hahn (HH) matching

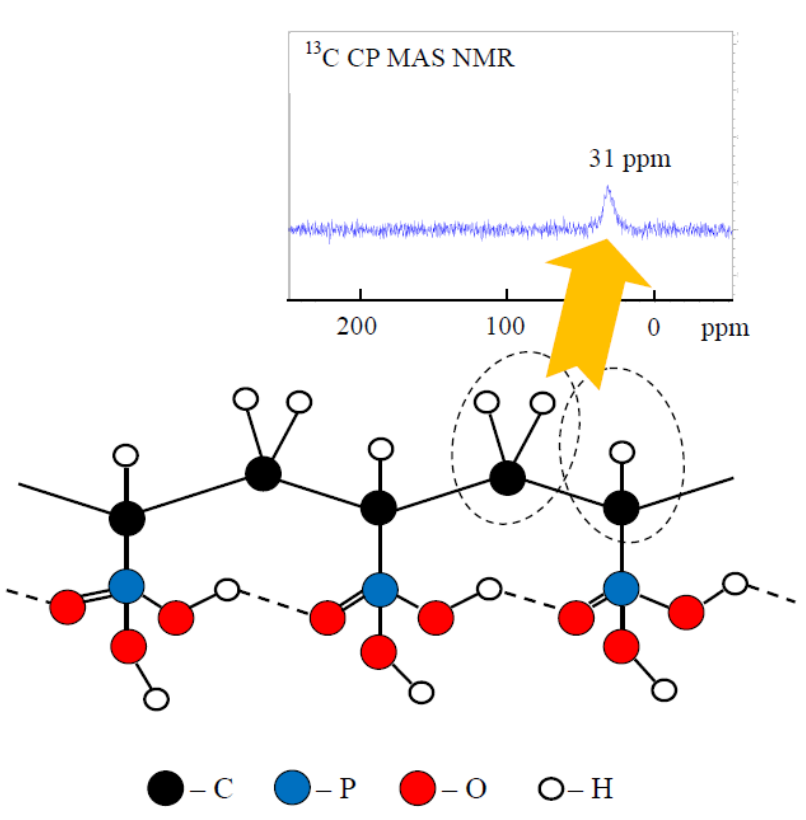

Fig. 1. Chemical structure of pVPA with the hydrogen-bond chain and ${ }^{13} \mathrm{C} C P$ MAS spectrum.

condition for the spinning sample. The sample was spun at a magic angle at $10 \mathrm{kHz}$ rate using a $4 \mathrm{~mm}$ zirconia rotor at room temperature. Spectra consisted of 3020 real data points and were accumulated by 16 scans with a repetition delay of $2.7 \mathrm{~s}$. The CP MAS kinetics were registered by varying the contact times from $10 \mu \mathrm{s}$ to $10 \mathrm{~ms}$ in increments of $10 \mu \mathrm{s}$. NMR spectra were processed using the Topspin 3.2 software. Some additional processing was carried out using the Microcal Origin 9 and MathCad 15.0 packages.

Impedance spectroscopy experiments were performed using a HP 4284A Precision LCR-meter. Dielectric measurements were carried out at $120-300 \mathrm{~K}$ temperature and $10^{2}-10^{6} \mathrm{~Hz}$ frequency ranges using the custom-made chamber for powder measurement. The temperature in the sample was controlled using a Keithley 2700 multimeter with a T-type thermocouple. The experimental data were collected during the cooling cycle at a cooling rate of $1 \mathrm{~K} / \mathrm{min}$. Low temperatures were achieved using the liquid nitrogen vapour.

\section{Theoretical models of CP kinetics}

The topic of CP kinetics, i.e. the dependence of $\mathrm{CP}$ signal intensity $I(t)$ on the contact time $(t)$, was reviewed in more detail in Refs. [1, 4 . The most widely used kinetic models that exhibit the coherent oscillatory behaviour of CP intensity originate from 
the work of Müller et al. [12]. The strongly coupled spin pair I-S $\left(\mathrm{I}={ }^{1} \mathrm{H}\right.$ and $\mathrm{S}={ }^{13} \mathrm{C}$ in the present work) was considered there as an open quantum system interacting with remote I spins. This effect was represented by an isotropic spin-diffusion superoperator [1, 12, 13]. The kinetics of the CP signal intensity $I(t)$ is then described by

$$
\begin{aligned}
& I(t)=I_{0} \mathrm{e}^{-\frac{t}{T_{1 \rho}}} \\
& \times\left[1-\frac{1}{2} \mathrm{e}^{-k_{1} t} \cos \left(2 \pi \frac{b}{2} t\right)-\frac{1}{2} \mathrm{e}^{-k_{2} t}\right],
\end{aligned}
$$

where $1 / T_{1 \rho}$ is the spin-lattice relaxation rate of spin I in the rotating frame, which was added by Naito and McDowell [13]. Parameters $k_{1}$ and $k_{2}$ are first-order rate constants that describe the decay of the transient oscillation and the increase in the net magnetization, respectively. In the case of isotropic spin diffusion the constraining relation is $k_{1}=3 k_{2} / 2$ [12, 14]. The parameter $b$ is dipolar splitting, which depends on the distance $r$ between the two nearest interacting nuclei (I and $S$ ) and on the angle $\theta$ between the $r$ vector and magnetic field direction:

$$
\begin{aligned}
& b=\frac{\mu_{0}}{4 \pi} \frac{\gamma_{\mathrm{I}} \gamma_{\mathrm{S}} \hbar}{r^{3}} \frac{3 \cos ^{2} \theta-1}{2} \\
& =D_{\mathrm{IS}} P_{2}(\cos \theta) .
\end{aligned}
$$

Later [14] Eq. (1) was developed for the extended spin-systems $\mathrm{S}-\mathrm{I}_{N}$ and under MAS,

$$
\begin{aligned}
& I(t)=I_{0}\left\{\frac{1}{2}\left[\mathrm{e}^{-\frac{t}{T_{\mathrm{I \rho}}}}-\mathrm{e}^{-k_{\mathrm{t}} t} g_{n}(t)\right]\right. \\
& \left.+\left(\frac{\langle S\rangle_{\mathrm{qe}}}{\omega_{0 \mathrm{I}}}-\frac{1}{2}\right)\left[\mathrm{e}^{-\frac{t}{T_{\mathrm{t \rho}}}}-\mathrm{e}^{-k_{2} t}\right]\right\},
\end{aligned}
$$

where $\omega_{0 I}$ is the Larmor frequency of I spins, and $\langle S\rangle_{\mathrm{qe}}$ is the quasi-equilibrium polarization of $S$ spin. In the thermal equilibrium $\langle S\rangle_{\mathrm{qe}}$ has the following form:

$$
\langle S\rangle_{\mathrm{qe}}=\frac{N}{N+1} \omega_{0 \mathrm{I}} .
$$

The function $g_{n}(t)$ in Eq. (3) incorporates the angular averaging as well as MAS effects on the cosfunction (Eq. (1)) with $n$ depending on which the $\mathrm{HH}$ sideband matching condition $\omega_{\mathrm{II}}-\omega_{\mathrm{IS}}=n \omega_{\mathrm{MAS}}$ was fulfilled [14]. In the case when the $b$ distribution and its Fourier image can be approached by Gaussian functions, the function $g_{n}(t)$ in Eq. (3) can be simply replaced by the Gaussian decay [5-7, 15]

$$
g_{n}(t)=\mathrm{e}^{-\frac{t^{2}}{2 T_{2}^{2}}},
$$

where the time constant $T_{2}$ is assumed to be approximately equal to the spin-spin relaxation time, at least at long contact times. Inserting Eqs. $(4,5)$ into Eq. (3), one obtains

$$
\begin{aligned}
& I(t)=I_{0}\left\{\left[\mathrm{e}^{-\frac{t}{T_{1 \rho}}}-\mathrm{e}^{-k_{1} t} \mathrm{e}^{-\frac{t^{2}}{2 T_{2}^{2}}}\right]\right. \\
& \left.+\left(\frac{N-1}{N+1}\right)\left[\mathrm{e}^{-\frac{t}{T_{1 \rho}}}-\mathrm{e}^{-k_{2} t}\right]\right\} .
\end{aligned}
$$

However, the coherent oscillatory behaviour, which is experimentally often observed in the initial stage of CP, is faded in the calculated curves when a Gaussian decay approach for $g_{n}(t)$ is applied. To refine the coherent oscillatory behaviour, a more precise averaging of $\cos (2 \pi b t / 2)$ has to be carried out. The digital averaging has been performed summing its values weighted by the fraction of spin pairs with a set of spatial parameters that corresponds to the oscillation frequency $b_{i} / 2$,

$$
\begin{aligned}
& g_{n}(t)=\overline{\cos \left(\frac{2 \pi b t}{2}\right)} \\
& =\sum_{i} P\left(b_{i} / 2\right) \cos \left(2 \pi b_{i} t / 2\right),
\end{aligned}
$$

where the normalized spin-coupling distribution $P(b)$ is introduced. Its profile is usually unknown and can be complex for soft disordered solids. Various shapes of $P(b)$ can be tested for the practical use in the processing of the experimental CP kinetic curves and the most proper one chosen [5, 15.

\section{Results and discussion}

Despite the fact that pVPA contains two carbon sites $\left(-\mathrm{CH}-\right.$ and $\left.-\mathrm{CH}_{2}-\right)$, due to a very small difference in the chemical shifts only the single signal at $\sim 31 \mathrm{ppm}$ was registered in the ${ }^{13} \mathrm{C}$ NMR spectrum (Fig. 1). The ${ }^{1} \mathrm{H} \rightarrow{ }^{13} \mathrm{C} \mathrm{CP}$ MAS kinetics were measured and processed for pVPA using a high density experimental data set (Fig. 2). As shown in 


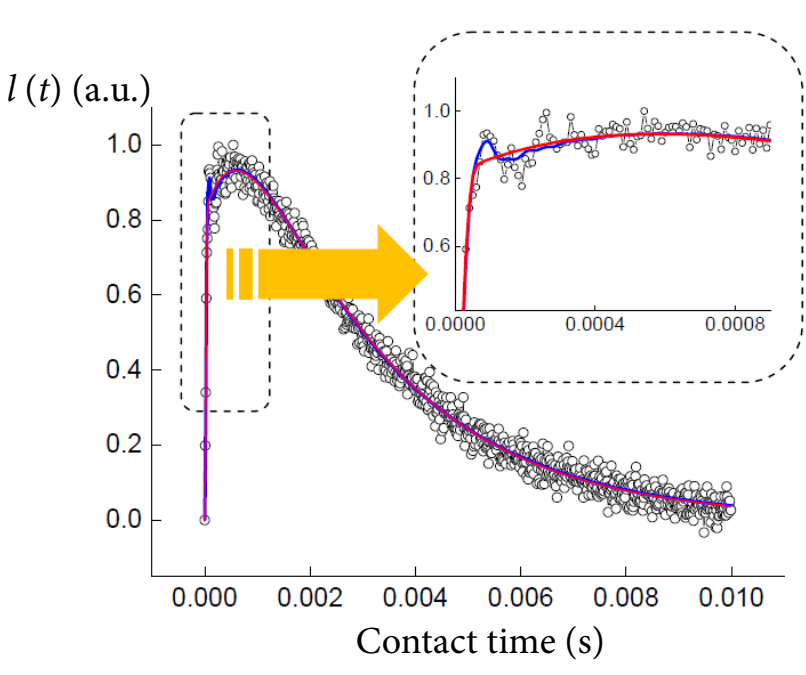

Fig. 2. The experimental ${ }^{1} \mathrm{H} \rightarrow{ }^{13} \mathrm{C}$ CP MAS kinetic data (circles) for $\mathrm{C}-\mathrm{H}$ and $\mathrm{C}-\mathrm{H}_{2}$ sites in $\mathrm{pVPA}$ at $10 \mathrm{kHz}$ MAS rate, processed using an isotropic spin-diffusion model $\left(k_{1} / k_{2}=3 / 2\right)$ with $T_{2}$-averaging (Eq. (6), a smooth red online line) and with cosineaveraging (Eqs. (3, 4, 7), a wavy blue online line). The fit parameter values are given in Table 1 .

the earlier works [5-7], this allows one to reduce the excessive freedom in the nonlinear curve fitting targeting its flow towards the 'true' minimum on the multi-parameter surface $\chi^{2}$, i.e. to the minimal sum of weighted squares of deviations of the chosen theoretical model curve from the experimental one. This enables one to test a series of multi-parametrical models.

Table 1. The fit parameters of ${ }^{1} \mathrm{H} \rightarrow{ }^{13} \mathrm{C}$ CP MAS kinetics of pVPA (Fig. 2) obtained using the models of isotropic spin diffusion $\left(k_{1} / k_{2}=3 / 2\right)$ with $T_{2}$-averaging and cosine-averaging with the Lorentz-shaped spincoupling distribution profile.

\begin{tabular}{cccc}
\hline \multicolumn{2}{c}{$\begin{array}{c}T_{2} \text {-averaging } \\
\text { (Eq. (6)) }\end{array}$} & \multicolumn{2}{c}{$\begin{array}{c}\text { cosine-averaging } \\
\text { (Eqs. }(3,4,7))\end{array}$} \\
\hline$N$ & $50 \pm 40$ & $N$ & 60 \\
\hline$k_{2}, \mathrm{~s}^{-1}$ & $1360 \pm 50$ & $k_{2}, \mathrm{~s}^{-1}$ & 1140 \\
$T_{\mathrm{dif}}, \mathrm{ms}$ & $0.74 \pm 0.06$ & $T_{\text {dif }}, \mathrm{ms}$ & 0.88 \\
\hline & & $b_{0}, \mathrm{~Hz}$ & 9900 \\
& & $b, \mathrm{~Hz}$ & 10700 \\
\hline \multirow{2}{*}{$T_{2}, \mu \mathrm{s}$} & \multirow{2}{*}{$20 \pm 1$} & $\Delta, \mathrm{Hz}$ & 8900 \\
& & $T_{2}=1 / \pi \Delta, \mu \mathrm{s}$ & 36 \\
\hline$T_{1 \rho}, \mathrm{ms}$ & $2.7 \pm 0.1$ & $T_{1 \rho}, \mathrm{ms}$ & 2.7 \\
\hline$R^{2} / \chi^{2}$ & $0.991 / 0.030$ & $R^{2} / \chi^{2}$ & $0.996 / 0.027$ \\
\hline
\end{tabular}

${ }^{*}$ The dipolar splitting values are taken for comparison from Fig. 3.
The experimental ${ }^{1} \mathrm{H} \rightarrow{ }^{13} \mathrm{C} \mathrm{CP}$ MAS kinetic data (Fig. 2) was processed applying the isotropic spindiffusion model with $T_{2}$-averaging with the constraint $k_{1} / k_{2}=3 / 2$, i.e. using Eq. (6), and the cosineaveraging routine (Eqs. $(3,4,7))$. We suggested to use the Lorentz function $L(b) \sim 1 /\left(1+\left(\left(b-b_{0}\right) / \Delta\right)^{2}\right)$ to approach the spin-coupling distribution profile $P(b)=L(b)$. In this case $T_{2}$ can be evaluated from the width of the Lorentz function $(\Delta)$ as $T_{2}=1 / \pi \Delta$. Smoothing of the coherent oscillatory behaviour due to a Gaussian decay approach for $g_{n}(t)$ (Eqs. (5, 6)) is demonstrated in detail (Fig. 2) at short contact time $(<0.8 \mathrm{~ms}$, see in the inset). The results of fitting are presented in Table 1 .

A significant advantage of solid-state NMR methods is the access to static structural details as well as the site-resolved dynamic order parameters associated with the mobility of different functional groups of complex molecules, like liquid crystals, polymers, proteins, etc., in the crystalline and powder samples [16, 17]. The obtained results on the CP MAS kinetics lead to certain conclusions on the fine dynamic features of pVPA as well.

It is gratifying to state that similar values of the ${ }^{13} \mathrm{C}-\left({ }^{1} \mathrm{H}\right)_{N}$ spin-cluster sizes $(N)$ have been obtained using both $T_{2}$ - and cosine-averaging models without any constraint on the flow of the nonlinear curve fitting $\left(\chi^{2} \rightarrow\right.$ minimum). Namely, the deduced values $N \approx(50-60) \pm 40$ (Table 1) can be recognized as the 'effective' number of spins I (protons) interacting with the carbons. Note the huge margins of the $N$ error that appear to be significantly larger than in the cases of other spin-systems in solids that are more rigid and thus more ordered $[6,8]$. Despite large errors, the finite value of $N$ means that the spin-coupling and the CP transfer cover several tens of neighbouring $\mathrm{C}-\mathrm{H}$ sites within $\mathrm{pVPA}$.

Monitoring of the changes in the dipole-dipole coupling allows the identification of dynamic processes undergoing in the sample. The local dynamic order parameter $S$ is defined as the ratio of the experimental dipolar coupling constant and the calculated static dipolar coupling constant [17-20]. In order to determine the experimental dipolar coupling constants the Fourier transform was carried out over the measured CP intensity kinetics $I(t)$ (Fig. 5). The obtained dipolar splitting values $(b)$ are almost identical with the maximum positions of the spin coupling distribution profile $\left(b_{0}\right)$, which 
were determined by fitting the experimental kinetic curves with the cosine-averaging model (Table 1).

The local order parameter $S$ was calculated in the well-known way [ $17-21]$ as

$$
S=\frac{D_{\mathrm{CH}}}{D_{\text {stat }}}=\left\langle P_{2}(\cos \alpha)\right\rangle,
$$

where $\alpha$ is the angle of instantaneous orientation of the dipole-dipole coupling tensor with respect to the 'symmetry axis of fast motion' [17] or the polar angle between the internuclear vector $\boldsymbol{r}_{\text {IS }}$ and the end-to-end vector of the polymer chain [21], $\langle\ldots\rangle$ represents the dynamic average over the molecular reorientations. The static constant $D_{\text {stat }}$ for the ${ }^{13} \mathrm{C}-{ }^{1} \mathrm{H}$ dipolar coupling was taken as $23.0 \pm 0.3 \mathrm{kHz}$ for the 'frozen' $\mathrm{C}-\mathrm{H}$ bond that corresponds to $r_{\mathrm{C}-\mathrm{H}} \sim 1.09-1.10 \AA$ (Eq. (2)).

The coupling constants $D_{\mathrm{CH}}$ were determined from the $b$ values, rescaling them by a factor of $\sqrt{2}$ because the $\mathrm{HH}$ matching for $n= \pm 1$ was fulfilled in the present experiments. Finally, the order parameter was calculated using the $D_{\mathrm{CH}}$ value as the average of those obtained from the dipolar splitting (Fig. 3) and the $b_{0}$ values from the curve fitting routine using a cosine-averaging model (Table 1). The obtained value $S=0.63 \pm 0.02$ points toward the significant local dynamic and disorder in $\mathrm{PVPA}$.

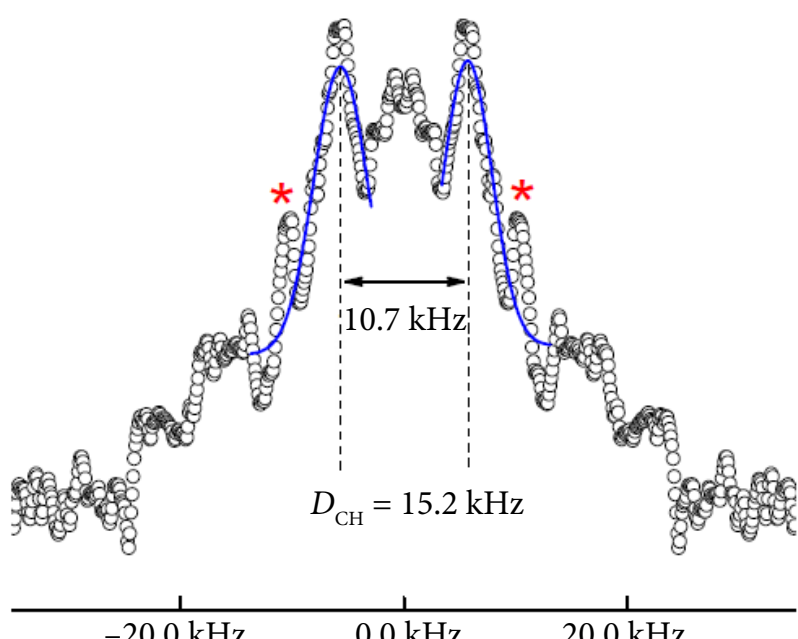

Fig. 3. The Fourier transform (FT) over the time dependence of CP intensity $I(t)$ for $\mathrm{C}-\mathrm{H}$ sites in pVPA (Fig. 2) apodized using a Gauss function (Eq. (5)) with the interactively adjusted $T_{2}=12 \mathrm{~ms}$ and the obtained dipolar splitting. The peaks at the MAS frequency $(10 \mathrm{kHz})$ that presumably can be related to periodic quasi-equilibriums are marked by asterisks $\left(^{*}\right)$. More comments are given in the text.
However, the abovementioned definitions of the angle $\alpha$ in Eq. (9), given in Refs. [17] and [21] (which are often identical), make the visualization of the local disorder in polymers and other complex molecules not obvious or even sophisticated. The simplified visualization can be done if the internal motion of vector $\boldsymbol{r}_{\mathrm{IS}}(t)$ is modelled as a restricted movement in a cone with the semi-angle $\theta_{\text {(Fig. 4) }}$. The order parameter $S$ is then given by [16, 19, 20]

$$
S=\cos \theta_{0}\left(1+\cos \theta_{0}\right) / 2
$$

The amplitude of this motion (bending, rocking, twisting, etc.) is qualitatively visualized by the cone semi-angle $\theta_{0}$. The $S$ and $\theta_{0}$ values for carbon sites in pVPA are given in Fig. 4. These values significantly differ from those obtained for proteins, other biological macromolecules and polymers [16, 18]. For instance, the $S$ values for $\mathrm{CH}, \mathrm{CH}_{2}$ and $\mathrm{CH}_{3}$ groups in poly(3-hydroxybutyrate) were found to be 0.81 , 0.80 and 0.43 , respectively [18]. Much higher $S$ values within $0.98-1.0$ were determined in more rigid and thus more ordered systems, like alanine and glycine $[8,19,20]$. Hence, the $S$ value obtained for

(a)
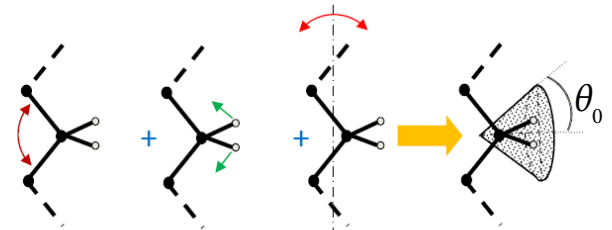

Bending

Wagging Pendulation

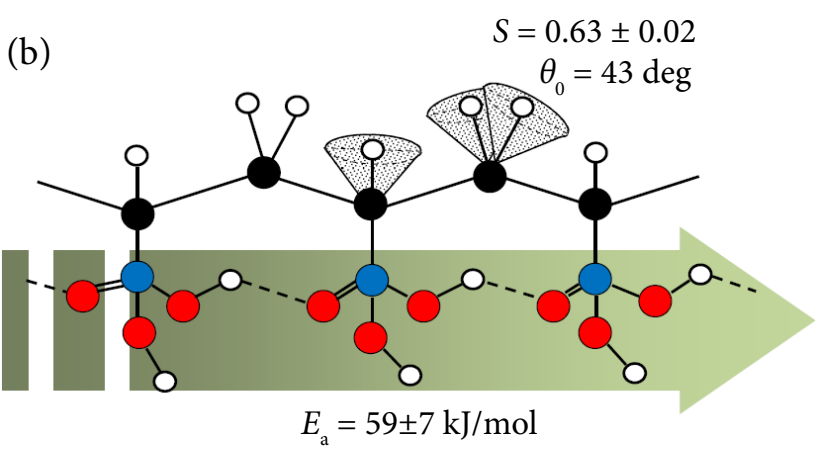

Fig. 4. The internal molecular motion modelled as restricted movement of the internuclear vector $\boldsymbol{r}_{\text {IS }}(t)$ in a cone (a); the order parameters $S$ and the visualization of the local disorder for carbon sites in pVPA (b). The activation energy of proton conductivity was determined from experimentally measured temperature and frequency dependences of complex dielectric permittivity (see Figs. 5, 6). 
pVPA is an intermediate case. Namely, according to the obtained $S$ value (Fig. A), the local disorder of the $\mathrm{C}-\mathrm{H}$ bonds in $\mathrm{pVBA}$ is between those for rather rigid $\mathrm{C}-\mathrm{H}$ bond configurations having $\mathrm{S}=0.8-1.0$ and highly disordered $-\mathrm{CH}_{3}$ groups $(S \sim 0.4)$.

The proton mobility along the $\mathrm{H}$-bond chain (Fig. 4) was studied by impedance spectroscopy. Dielectric spectroscopy experiments for pVPA were performed in the $120-300 \mathrm{~K}$ temperature range. The temperature dependences of real $\left(\varepsilon^{\prime}\right)$ and imaginary $\left(\varepsilon^{\prime \prime}\right)$ parts of the complex dielectric permittivity $\varepsilon^{\star}=\varepsilon^{\prime}-\mathrm{i} \varepsilon^{\prime \prime}$ of $\mathrm{pVPA}$ powder are shown in Fig. 5. At low temperatures, the experimental real part of dielectric permittivity shows a stable value of 2.8. A sharp increase in complex dielectric permittivity values is observed at high temperatures (above $225 \mathrm{~K}$ ) that is typical for relaxations due to mobile charge carriers. In the further processing of experimental data the real part of conductivity $\sigma$ > was calculated as

$$
\sigma^{\prime}=\omega \varepsilon_{0} \varepsilon^{\prime \prime}(\omega)
$$

where $\omega$ is the angular frequency and $\varepsilon_{0}$ is the dielectric permittivity of vacuum. According to the Jonscher power law, $\sigma^{\prime}$ is related to the direct current conductivity $\sigma_{\mathrm{DC}}$ :

$$
\sigma^{\prime}=\sigma_{\mathrm{DC}}+A \omega^{s}
$$

Here $A$ and $S$ are the constants. The $\sigma_{\mathrm{DC}}$ values were estimated using Eq. (12) and the experimental

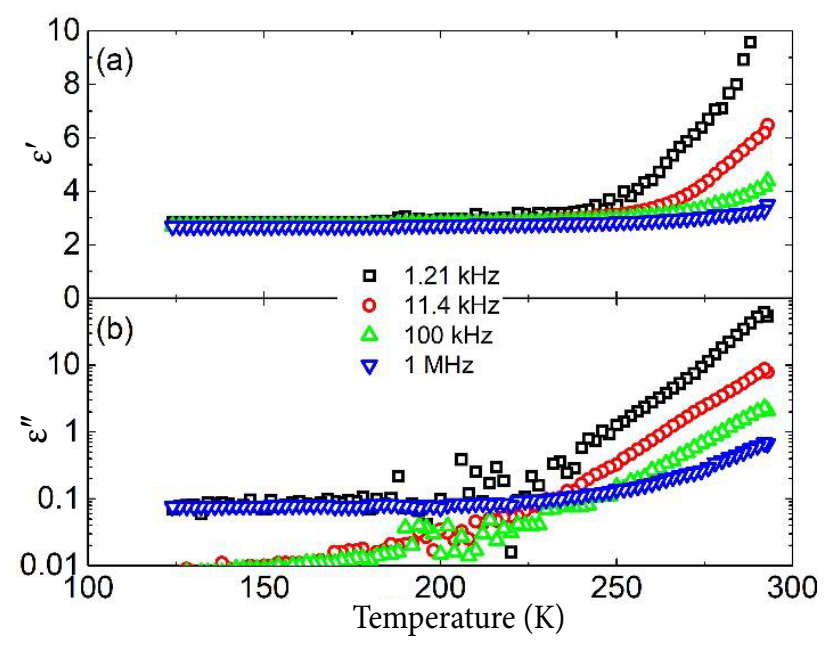

Fig. 5. Temperature dependences of the real (a) and imaginary (b) parts of the complex dielectric permittivity of pVPA at various frequencies. set of the frequency dependences of conductivity at various temperatures. The dependence of $\sigma_{\mathrm{DC}}$ on temperature is presented as the Arrhenius plot in Fig. 6.

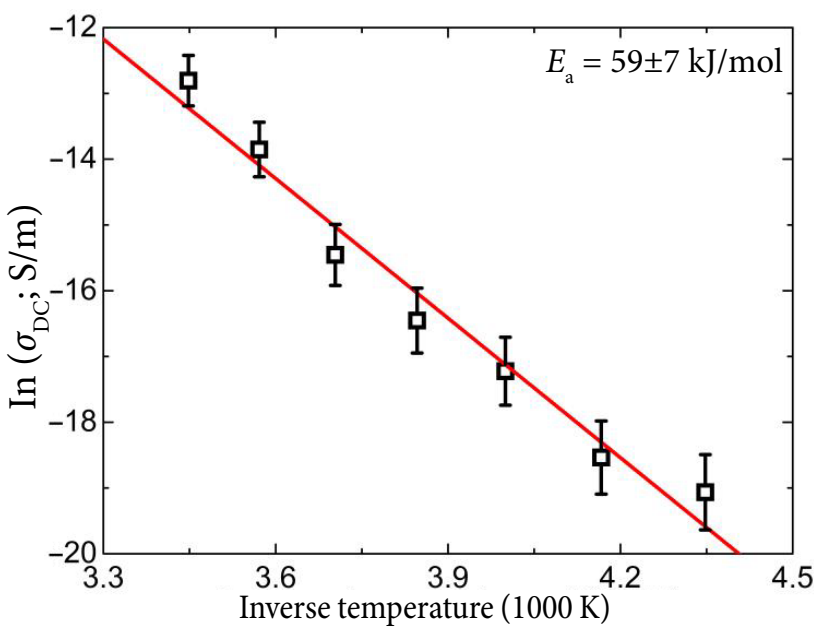

Fig. 6. The Arrhenius plot of $\sigma_{\mathrm{DC}}$ of proton conductivity in $\mathrm{pVPA}$ powder.

The determined activation energy $E_{\mathrm{a}}=59 \pm 7 \mathrm{~kJ} /$ mol in pVPA powder (Fig. 6) is comparable with the values 45 and $65 \mathrm{~kJ} / \mathrm{mol}$ obtained for as-prepared and annealed pVPA, respectively [10]. However, it is lower than in the pVPA/poly(ethylene oxide) (PEO) blends (from 95 to $78 \mathrm{~kJ} / \mathrm{mol}$, depending on the PEO content in the blend) [11]. As there are no other mobile species than protons, the proton conductivity in pVPA can be realized via $\mathrm{H}$-bond breaking and forming processes only. The above $E_{\mathrm{a}}$ values fit well into a general vista of $\mathrm{H}$-bond energies and point to a two-step Grotthuss mechanism for proton migration: (1) displacement of a proton along a hydrogen bond; (2) transfer of the proton to another oxygen with formation of a new H-bond [10, 11]. The Arrhenius type behaviour of the proton conductivity means that the polymer chain motion has no significant effect on the proton dynamics [11]. On the other hand, it can be supposed that the presence of the proton-motion 'highway' (Fig. 4) significantly accelerates the spin-lattice relaxation process in pVPA. The spin-lattice relaxation rate of protons in the rotating frame $1 / T_{1 \rho}$ is almost one order faster (Table 1) than those observed for other polymers without proton conductivity paths [22]. In relation to this, it is interesting to note the presence of narrow peaks at multiples of the MAS frequency in the dipole coupling distribution profile $(10 \mathrm{kHz}$, Fig. 3). 
The presence of such peaks is considered as the confirmation of the existence of a periodic quasi-equilibrium state having a lifetime depending on $T_{1 \rho}[23]$. Such peaks have been observed in other systems: glycine [8], ferrocene and alanine [23], as well as in some polymers - poly(3-hydroxybutyrate) [18] and poly(2-hydroxyethyl methacrylate) (pHEMA) [22], where $T_{1 \rho}$ is definitely longer than the spin-diffusion time, i.e. $T_{1 \rho} \gg 1 / k_{2}$. Therefore the fact itself that the peaks in the pVPA dipole coupling distribution profile are discerned at $10 \mathrm{kHz}$ MAS (Fig. 3) even in such limiting case $T_{1 \rho} \sim T_{\text {dif }}=1 / k_{2}$ (Table 1 ) is quite remarkable. For rigorous confirmation the advanced CP MAS experiment has to be carried out achieving a better signal-to-noise ratio.

\section{Conclusions}

It can be stated that the isotropic spin-diffusion approach well describes the ${ }^{1} \mathrm{H} \rightarrow{ }^{13} \mathrm{C} \mathrm{CP}$ kinetics in pVPA, i.e. in the spin-system containing the adjacent (or directly bonded) spins. The best fit between experimental data and theory was achieved applying the averaging model with the Lorentz spincoupling distribution profile that reproduces coherent CP intensity oscillations in the initial stage of polarization transfer (at short contact times). The rates of spin-lattice relaxation of protons and spin diffusion are of the same order and both occur in the time scale of milliseconds.

The values of the spin-cluster size $(N \sim 50 \pm 40)$ have been obtained for this spin-system without any constraint on the flow of the nonlinear curve fitting. Despite large errors, the finite value of $N$ means that the $\mathrm{CP}$ transfer process covers several tens of neighbouring $\mathrm{C}-\mathrm{H}$ sites within $\mathrm{pVPA}$.

According to the determined value of the order parameter $(S=0.63 \pm 0.02)$, the local disorder of the $\mathrm{C}-\mathrm{H}$ bonds in pVPA is between those for rather rigid $\mathrm{C}-\mathrm{H}$ bond configurations having $S=0.8-$ 1.0 and for highly disordered $-\mathrm{CH}_{3}$ groups when $S \sim 0.4$. Probably, this is due to the mutual influence of the $\mathrm{C}-\mathrm{H}$ mobility and the proton transfer along the $\mathrm{H}$-bond chain, which is characterized by relatively low activation energy $\left(E_{\mathrm{a}}=59 \pm 7 \mathrm{~kJ} / \mathrm{mol}\right)$.

\section{Acknowledgements}

The authors acknowledge the Center of Spectroscopic Characterization of Materials and
Electronic/Molecular Processes ('SPECTROVERSUM', www.spectroversum.ff.vu.lt) at the Lithuanian National Center for Physical Sciences and Technology for the use of spectroscopic equipment. One of us (V. Chizhik) thanks the Magnetic Resonance Group for the hospitality during his research stay in the frame of the Agreement of Collaboration between Saint Petersburg and Vilnius Universities.

\section{References}

[1] J. Raya and J. Hirschinger, Sensitivity enhancement by multiple-contact cross-polarization under magic-angle spinning, J. Magn. Reson. 281, 253-271 (2017).

[2] E.O. Stejskal, J. Schaefer, and J.S. Waugh, Magicangle spinning and polarization transfer in proton-enhanced NMR, J. Magn. Reson. 28, 105-112 (1977).

[3] E.O. Stejskal and J.D. Memory, High Resolution NMR in the Solid State: Fundamentals of CP/MAS (Oxford University Press, New York, 1994).

[4] W. Kolodziejski and J. Klinowski, Kinetics of cross-polarization in solid-state NMR: A guide for chemists, Chem. Rev. 102, 613-628 (2002).

[5] V. Klimavicius, L. Dagys, and V. Balevicius, Subnanoscale order and spin diffusion in complex solids through the processing of cross-polarization kinetics, J. Phys. Chem. C 120, 3542-3549 (2016).

[6] L. Dagys, V. Klimavicius, and V. Balevicius, Processing of CP MAS kinetics: Towards NMR crystallography for complex solids, J. Chem. Phys. 145, 114202 (2016).

[7] V. Klimavicius, L. Dagys, V. Chizhik, and V. Balevicius, CP MAS kinetics study of ionic liquids confined in mesoporous silica: Convergence of non-classical and classical spin coupling models, Appl. Magn. Reson. 48, 673-685 (2017).

[8] L. Dagys, V. Klimavicius, T. Gutmann, G. Buntkowsky, and V. Balevicius, Quasi-equilibria and polarization transfer between adjacent and remote spins: ${ }^{1} \mathrm{H}-{ }^{13} \mathrm{C}$ CP MAS kinetics in glycine, J. Phys. Chem. A 122, 8938-8947 (2018).

[9] S. Asami and B. Reif, Comparative Study of REDOR and CPPI derived order parameters by 
${ }^{1} \mathrm{H}$-detected MAS NMR and MD simulations, J. Phys. Chem. B 121, 8719-8730 (2017).

[10]Y.J. Lee, B. Bingöl, T. Murakhtina, D. Sebastiani, W.H. Meyer, G. Wegner, and H.W. Spiess, Highresolution solid-state NMR studies of poly(vinyl phosphonic acid) proton-conducting polymer: Molecular structure and proton dynamics, J. Phys. Chem. B 111, 9711-9721 (2007).

[11]F. Jiang, H. Zhu, R. Graf, W.H. Meyer, H.W. Spiess, and G. Wegner, Phase behaviour and proton conduction in poly(vinylphosphonic acid)/poly (ethylene oxide) blends, Macromolecules 43, 3876-3881 (2010).

[12]L. Müller, A. Kumar, T. Baumann, and R.R. Ernst, Transient oscillations in NMR cross-polarization experiments in solids, Phys. Rev. Lett. 32, 14021406 (1974).

[13]A. Naito and C.A. McDowell, Anisotropic behaviour of the ${ }^{13} \mathrm{C}$ nuclear spin dynamics in a single crystal of L-alanine, J. Chem. Phys. 84, 4181-4186 (1986).

[14]S. Hediger, Improvement of Heteronuclear Polarization Transfer in Solid-State NMR, Ph. D. Thesis (ETH-Zürich, 1997).

[15]V. Klimavicius, A. Kareiva, and V. Balevicius, Solid-state NMR study of hydroxyapatite containing amorphous phosphate phase and nanostructured hydroxyapatite: Cut-off averaging of CP MAS kinetics and size profiles of spin clusters, J. Phys. Chem. C 118, 28914-28921 (2014).

[16]A.G. Palmer III, J. Williams, and A. McDermott, Nuclear magnetic resonance studies of biopolymer dynamics, J. Phys. Chem. 100, 13293-13310 (1996).
[17]K. Saalwächter and H.W. Spiess, in: Polymer Science: A Comprehensive Reference, Vol. 2, eds. K. Matyjaszewski and M. Möller (Elsevier Science, 2012) pp. 185-219.

[18]M. Koval'aková, O. Fričová, M. Hutníková, V. Hronský, and D. Olčák, Dynamics of ${ }^{1} \mathrm{H}-{ }^{13} \mathrm{C}$ cross polarization in nuclear magnetic resonance of poly(3-hydroxybutyrate), Acta Phys. Pol. A 131, 1162-1164 (2017).

[19]J.L. Lorieau and A.E. McDermott, Conformational flexibility of a microcrystalline globular protein: Order parameters by solid-state NMR spectroscopy, J. Am. Chem. Soc. 128, 1150511512 (2006).

[20]J.L. Lorieau and A.E. McDermott, Order parameters based on ${ }^{13} \mathrm{C}^{1} \mathrm{H},{ }^{13} \mathrm{C}^{1} \mathrm{H}_{2}$ and ${ }^{13} \mathrm{C}^{1} \mathrm{H}_{3}$ heteronuclear dipolar powder patterns: A comparison of MAS-based solid-state NMR sequences, Magn. Reson. Chem. 44, 334-347 (2006).

[21]M. Wang, M. Bertmer, D.E. Demco, and B. Blümich, Segmental and local chain mobilities in elastomers by ${ }^{13} \mathrm{C}-{ }^{1} \mathrm{H}$ residual heteronuclear dipolar couplings, J. Phys. Chem. B 108, 1091110918 (2004).

[22]L. Dagys, V. Klimkevičius, V. Klimavicius, K. Aidas, R. Makuška, and V. Balevicius, CP MAS kinetics in soft matter: spin diffusion, local disorder and thermal equilibration in poly(2-hydroxyethyl methacrylate) [to be published].

[23]D. Sakellariou, P. Hodgkinson, S. Hediger, and L. Emsley, Experimental observation of periodic quasi equilibria in solid-state NMR, Chem. Phys. Lett. 308, 381-389 (1999). 


\title{
LOKALIOSIOS NETVARKOS ŽEMOS DIMENSIJOS H-RYŠIO PROTONŲ LAIDININKUOSE TYRIMAI CP MAS KINETIKOS IR IMPEDANSO SPEKTROMETRIJOS METODAIS
}

\author{
L. Dagys a,b, S. Balčiūnas ${ }^{c}$, J. Banys ${ }^{\text {c }}$, F. Kuliešius a , V. Chizhik ${ }^{\text {d, }}$, V. Balevičius ${ }^{\text {a }}$ \\ ${ }^{a}$ Vilniaus universiteto Cheminès fizikos institutas, Vilnius, Lietuva \\ b Soutamptono universiteto Chemijos katedra, Soutamptonas, Jungtine Karalyste \\ ${ }^{c}$ Vilniaus universiteto Taikomosios elektrodinamikos ir telekomunikaciju institutas, Vilnius, Lietuva \\ ${ }^{\mathrm{d}}$ Sankt Peterburgo valstybinio universiteto Fizikos fakultetas, Sankt Peterburgas, Rusija
}

\begin{abstract}
Santrauka
Ištirta ${ }^{1} \mathrm{H}-{ }^{13} \mathrm{C} \mathrm{CP}$ (kryžminès poliarizacijos) MAS (magiško kampo sukimo) kinetika, vykstanti poli(vinyl fosfoninèje rūgštyje) (pVPA), t. y. medžiagoje, kuriai būdingas didelis protonų judejjimo išilgai vandenilinių ryšių (H-ryšių) grandinès laisvès laipsnių skaičius. Dèl šios savybės pVPA priskiriama medžiagų klasei, vadinamajai protonų laidininkei. Parodyta, kad šioje medžiagoje vykstančios CP MAS kinetikos eksperimentiniai duomenys gali būti aprašyti taikant izotropinès sukinių difuzijos modelị. Nustatytos sukinių difuzijos bei sukinių ir gardelès relaksacijų spartos, taip pat parametrai, nusakantys ${ }^{1} \mathrm{H}$ ir ${ }^{13} \mathrm{C}$ sukinių sąveiką ir efektyviuosius sukinių spiečių matmenis. Lokaliosios tvarkos parametras $S \approx 0,63 \pm 0,02$, apskaičiuotas remiantis eksperimentiškai išmatuotos dipolinès ${ }^{1} \mathrm{H}-{ }^{13} \mathrm{C}$ sąveikos konstantos ir
\end{abstract}

apskaičiuotosios statinès konstantos vertèmis, yra daug mažesnis už S vertes, kurios aptinkamos daugelyje giminingų molekuliniams fragmentams polimeru ir amino rūgščių serijose. Lokalioji $\mathrm{C}-\mathrm{H}$ jungčių netvarka pVPA užima tarpinę padètį tarp stingiujuc $\mathrm{C}-\mathrm{H}$ konfigūracijų, kurioms yra būdingos $S$ vertès, artimos $1,0(S=0,8-1,0)$, ir metilo $\left(-\mathrm{CH}_{3}\right)$ grupių, kurių didelè netvarka $(S \sim 0,4)$ atsiranda dèl lengvai aktyvuojamo šių grupių sukimosi. Galima teigti, kad nemažas C-H jungčių tvarkos parametro sumažèjimas yra nulemtas intensyvaus rūgštinių protonų judejjimo išilgai H-ryšių grandinès. Impedanso spektroskopijos metodu nustatyta šio judesio aktyvavimo energija yra $E_{\mathrm{a}}=59 \pm 7 \mathrm{~kJ} / \mathrm{mol}$. Sukinių difuzijos bei sukinių ir gardelès relaksacijos spartos tirtajame polimere yra tos pačios eilès, ir šie vyksmai prateka milisekundžių skalèje. 